NASA/TM-1998-208500

N. 34

Evaluation of Low Earth Orbit Environmental Effects on International Space Station Thermal Control Materials

Joyce A. Dever and Sharon K. Rutledge

Lewis Research Center, Cleveland, Ohio

Mark M. Hasegawa

Boeing Space and Defense Systems, Huntington Beach, California

Charles K. Reed

Lockheed Martin Vought Systems, Dallas, Texas

Prepared for the International Conference on Protection of Materials in a Space Environment sponsored by the University of Toronto Institute for Aerospace Studies Toronto, Canada, April 23-24, 1998

National Aeronautics and Space Administration

Lewis Research Center 
Trade names or manufacturers' names are used in this report for identification only. This usage does not constitute an official endorsement, either expressed or implied, by the National Aeronautics and Space Admiristration.

Available from

NASA Center for Aerospace Information

7121 Standard Drive

Hanover, MD 21076

Price Code: A03
National Technical Information Service 5287 Port Royal Road Springfield, VA 22100

Price Code: A03 


\title{
EVALUATION OF LOW EARTH ORBIT ENVIRONMENTAL EFFECTS ON INTERNATIONAL SPACE STATION THERMAL CONTROL MATERIALS
}

\author{
JOYCE A. DEVER \\ SHARON K. RUTLEDGE \\ NASA Lewis Research Center \\ Cleveland, $\mathrm{OH} 44135$ \\ MARK M. HASEGAWA \\ Boeing Space and Defense Systems \\ Huntington Beach, CA 92647 \\ CHARLES K. REED \\ Lockheed Martin Vought Systems \\ Dallas, TX 75265
}

\begin{abstract}
Samples of International Space Station (ISS) thermal control coatings were exposed to simulated low Earth orbit (LEO) environmental conditions to determine effects on optical properties. In one test, samples of the white paint coating Z-93P were coated with outgassed products from Tefzel ${ }^{\$}$ (ethylene tetrafluoroethylene copolymer) power cable insulation as may occur on ISS. These samples were then exposed, along with an uncontaminated Z-93P witness sample, to vacuum ultraviolet (VUV) radiation to determine solar absorptance degradation. The Z-93P samples coated with Tefzel ${ }^{\star}$ outgassing products experienced greater increases in solar absorptance than witness samples not coated with Tefzel ${ }^{\otimes}$ outgassing products. In another test, samples of second surface silvered Teflon ${ }^{\otimes}$ FEP (fluorinated ethylene propylene), $\mathrm{SiO}_{\mathrm{x}}$ (where $\mathrm{x} \approx 2$ )-coated silvered Teflon ${ }^{\circ E P}$, and $\mathrm{Z}$-93P witness samples were exposed to the combined environments of atomic oxygen and VUV radiation to determine optical properties changes due to these simulated ISS environmental effects. This test verified the durability of these materials in the absence of contaminants.
\end{abstract}

\section{Introduction}

In low Earth orbit (LEO), solar ultraviolet (UV) radiation and atomic oxygen can cause changes to the solar absorptance of many thermal control coatings. UV radiation can cause darkening, indicated by an increase in solar absorptance, of some polymers and oxides commonly used in thermal control materials. Atomic oxygen can cause erosion of polymer materials, but may reverse the UV-darkening effect on oxides. Maintenance of low solar absorptance and high thermal emittance of thermal control coatings is important to assure the proper operating temperature of thermal control systems. Thermal control coatings to be used on radiator surfaces of the International Space Station (ISS) were evaluated for their performance upon exposure to simulated LEO environments of solar vacuum ultraviolet (VUV) radiation (wavelength range $115-200 \mathrm{~nm}$ ) and VUV combined with atomic oxygen (AO). Solar absorptance measurements were made in vacuum in order to eliminate the "bleaching effect," or reversal of degradation due to ambient oxygen exposure, on VUV-induced degradation. For comparison, solar absorptance measurements were also made in air before and after the exposure tests. For some samples, thermal emittance was also measured in air. The objectives of these experiments were to determine changes in optical properties for various thermal control materials due to exposure to simulated LEO conditions similar to those expected for ISS. In one test, samples of the white paint thermal control coating Z-93P (zinc oxide pigment in potassium silicate binder) were coated with outgassed products from a radiation crosslinked Tefzel ${ }^{\circledast}$ (ethylene tetrafluoroethylene copolymer) to simulate possible on-orbit contamination from power cable insulation. Samples were then exposed to VUV radiation to determine the solar absorptance degradation that would be expected due to VUV-induced darkening of both the Z-93P and the contaminant layer. This test represented a worst-case scenario for Z-93P solar absorptance degradation because $\mathrm{AO}$, which may remove some of the contaminants and may reverse the darkening due to 
vacuum ultraviolet radiation, was not present during testing. In another set of tests, samples of silvered Teflon ${ }^{(\mathbb{t}}$ FEP (fluorinated ethylene propylene), $\mathrm{SiO}_{\mathrm{x}}$ (where $\mathrm{x} \approx 2$ )-coated silvered FEP Teflon ${ }^{\star}$, and white paint Z-93P coatings were exposed to AO combined with VUV radiation in order to verify the solar absorptance and thermal emittance durability of these thermal control materials selected for use on the ISS. These samples were not exposed to contamination prior to AO-VUV testing.

\section{Experimental Procedures}

\subsection{VUV AND COMBINED AO-VUV EXPOSURE FACILITY}

The facility that was used in these experiments for VUV exposure and combined AO-VUV exposure is described in [1] and [2]. Four samples of maximum size $2.5 \mathrm{~cm}$ diameter and $0.535 \mathrm{~cm}$ thickness can be exposed to atomic oxygen and VUV radiation concurrently or to the individual environmental effects. These four samples can be measured, in vacuum, for total hemispherical reflectance. A schematic diagram of the facility is given in Figure 1.

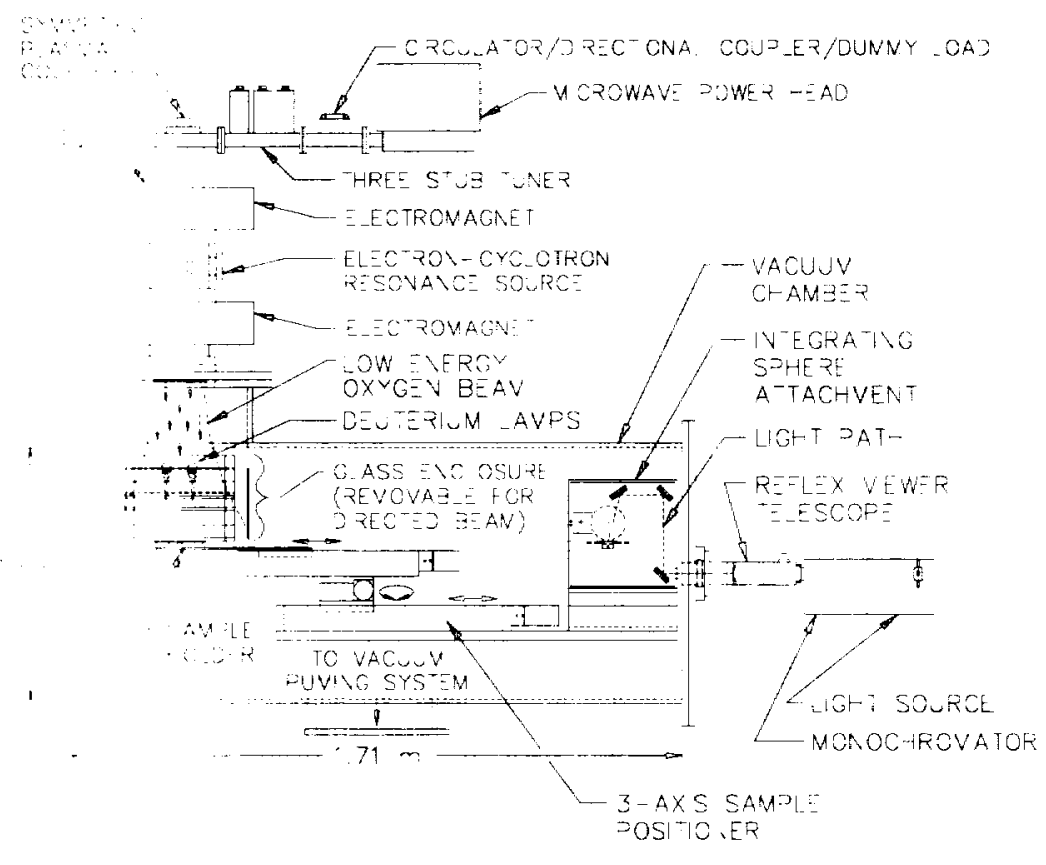

Figure 1: Atomic oxygen-vacuum ultraviolet radia ion exposure facility.

An ECR (electron cyclotron resonance) source is used to provide ther mal energy atomic oxygen. To avoid direct line-of-sight to the samples from the ECR source, which also provides intense VUV at the $130 \mathrm{~nm}$ oxygen resonance line, a fixture consisting of glass surfaces and an aluminum foil liner are used to scatter and redirect the atomic oxygen. Mass change of Teflon ${ }^{\star}$ FEP, whose in-space erosion yield has been characterized as $3.64 \times 10^{-25} \mathrm{~cm}^{3} /$ atom [3], was used to determine equivalent atomic oxygen flux and fluence during each AO-VUV exposure test. A pair of deuterium lamps was used for VUV exposure. These lamps are described in section 2.2. The in-vacuum reflectance measurement capability is described in section 2.3.2. Facility pressure was approximately $4 \times 10^{-6}$ to $10^{-5}$ torr during VUV exposure of samples without $\mathrm{AO}$, and approximately $4 \times 10^{4}$ torr during combined VUV and $\mathrm{AO}$ exposure. 


\subsection{VUV LAMP AND DETECTOR CALIBRATION PROCEDURES}

For each test, a pair of 30 watt deuterium lamps (Hamamatsu model L879-01) with magnesium fluoride windows were used to illuminate samples in a 4-sample holder located inside the vacuum chamber as shown in Figure 1. The distance between the lamp's anode and the center of the sample holder was approximately $49.5 \mathrm{~cm}$ where distance was measured along the axis of the lamp nose. The bodies of the lamps were located outside of the vacuum chamber with their end-tubes pushed through o-ring compression fittings to provide a vacuum seal. The lamps' end-tube windows were thus located inside the vacuum chamber. Lamp bodies were cooled with forced air.

Prior to and following each test, the output of the pair of lamps was measured in vacuum using a cesium iodide (CsI) phototube (Hamamatsu Model R1187) with a magnesium fluoride window. The CsI phototube was attached to the 4-sample holder with its axis along the lamp nose axis with the sensor at the level of the sample surfaces. The phototube was then placed at each of the four sample sites to obtain signal at that position. This phototube is sensitive in the wavelength range between 115 and $200 \mathrm{~nm}$, the range of primary output of the deuterium lamps.

Prior to measuring the output of the exposure lamps, the CsI phototube was calibrated at $25.4 \mathrm{~cm}$ distance with a Hamamatsu L879-01 lamp used as a reference standard. This lamp had been calibrated at $25.4 \mathrm{~cm}$ distance by the National Institute of Standards and Technology (NIST). The intensity obtained by NIST was divided by the CsI phototube-measured signal for the reference standard lamp to determine a calibration factor for the detector for the wavelength range of $115-200 \mathrm{~nm}$. Detector calibration data is shown in Table 1.

TABLE 1. VUV Detector Calibration Data

\begin{tabular}{ll}
\hline Parameter & Value \\
\hline Intensity of NIST-calibrated VUV lamp, $25.4 \mathrm{~cm}$ & \\
distance, $115-200 \mathrm{~nm}$ & $3.39 \times 10^{-4} \mathrm{~W} / \mathrm{cm}^{2}$ \\
Intensity of the sun, air mass zero, 115-200 nm & $1.0378 \times 10^{-5} \mathrm{~W} / \mathrm{cm}^{2}$ \\
Signal of NIST-calibrated VUV lamp measured & \\
$\quad$ with CsI detector, 25.4 cm distance & $1.68 \times 10^{-6} \mathrm{~A}$ \\
Calibration factor for CsI detector & $201.79 \mathrm{~W} /\left(\mathrm{cm}^{2} \cdot \mathrm{A}\right)$ \\
\hline
\end{tabular}

For each pair of lamps measured using the calibrated CsI detector, the signal obtained in amps was multiplied by the detector's calibration factor to give the lamp intensity in the wavelength range 115-200 nm. Dividing the lamps' intensity by the sun's intensity in the same wavelength range provided the number of suns in the 115-200 nm range. For each VUV exposure test, equivalent sun hours (ESH) of VUV exposure in the $115-200 \mathrm{~nm}$ wavelength range were obtained using the following equation:

$$
(\text { ESH VUV })_{115-200 \mathrm{~mm}}=(\text { No. of Suns })_{115-200 \mathrm{~nm}} \times(\text { Exposure duration, hrs. })
$$

Measured lamp intensity data and ESH for each of the exposure tests will be given in sections 3.1 and 3.2.

\subsection{OPTICAL PROPERTIES CHARACTERIZATION PROCEDURES}

\subsubsection{In-air Solar Absorptance Measurements}

Prior to and following VUV or AO-VUV exposure tests, samples were measured for total hemispherical reflectance in air between 250 and $2500 \mathrm{~nm}$ using a Perkin-Elmer Lambda-9 spectrophotometer equipped with a $15 \mathrm{~cm}$ integrating sphere. A Labsphere Spectralon reference standard was used. Solar reflectance, $\rho_{s}$, was obtained by integrating spectral reflectance over the air mass zero solar spectral irradiance distribution using standard procedures [4]. Because samples were opaque, solar absorptance, $\alpha_{s}$, was obtained using the following equation:

$$
\alpha_{\mathrm{s}}=1-\rho_{\mathrm{s}}
$$

Error in repeatability of $\alpha_{5}$ measurements with the Lambda- 9 instrument is expected to be approximately \pm 0.005 . 


\subsubsection{In-vacuum Reflectance Measurement System: Calibration and Use}

The reflectance measurement system, Optronic Laboratories Model 746 (OL 746), is described in detail in [2]. This system measures total hemispherical spectral reflectance in the wavelength range from 280 to $2500 \mathrm{~nm}$. Calculations of solar absorptance were made in this wavelength range using standard procedures [4] and solar absorptance was calculated using Equation 2.

Because the OL 746 is a single beam instrument, a known reference is measured in order to calibrate the system prior to measuring test samples. Calibration factors as a function of wavelength, $\lambda$, are obtained in the form of

$$
(\text { Cal. factor })_{\lambda}=(\text { Reference Reflectance })_{\lambda} /(\text { measured detector signal })_{\lambda} \text {. }
$$

The reference sample used for these experiments was a sample of YB-71 (white paint thermal control coating comprised of zinc orthotitanate pigment in a potassium silicate binder) on aluminum, which was located in the integrating sphere attachment of the OL 746 and protected from VUV and AO exposure. The absolute reflectance of this sample was previously measured in air using the Perkin-Elmer Lambda-9 instrument as described in section 2.3.1. These in-air data were used in Equation 3 as the (Reference Reflectance) $\lambda$ values.

Samples in the 4-sample holder are transported from the AO-VUV exposure end of the chamber to the measurement end of the chamber using a three-axis positioner to which the sample holder is mounted, as shown in Figure 1. Because samples slide into place under the integrating sphere for measurement, a small gap is needed between the integrating sphere port and the sample surface. This can introduce error in the measurement of reflectance due to loss of light from this gap. In order to reduce this error, the pre-test, in-air reflectance measurement of each sample obtained with the OL 746 was compared to an in-air measurement obtained with the Perkin-Elmer Lambda-9 where samples were in intimate contact with the integrating sphere. For these in-air data, a set of correction factors was generated for each sample so that the reflectance at each wavelength measured with the OL 746 instrument was corrected to the value given by the Lambda-9. These spectral correction factors were applied to each subsequent reflectance spectrum obtained with the OL 746 instrument. Error in repeatability of $\alpha_{s}$ measurements with the OL 746 instrument is expected to be approximately \pm 0.01 .

\subsubsection{In-air Thermal Emittance Measurements}

A Gier-Dunkle model DB-100 portable emissometer was used to measure room temperature total emittance, $\varepsilon$, normal to sample surfaces. The instrument provides an integrated value of normal emittance over the wavelength range of 5 to $25 \mu \mathrm{m}$. Error in repeatability of measurement of $\varepsilon$ is expected to be approximately \pm 0.005 .

\subsection{TEFZEL ${ }^{\circledR}$-CONTAMINATED Z-93P EXPOSED TO VUV WITFOUT AO}

\subsubsection{Samples}

The white paint coating Z-93P was applied to aluminum substrates of $2.38 \mathrm{~cm}$ diameter. Coating thickness was approximately $0.10-0.13 \mathrm{~mm}$. Samples of Z-93P were coated with approximately $100 \mathrm{~nm}$ of outgassed products from a radiation crosslinked Tefzel ${ }^{\Phi}$ as described fully in [5]. Samp es of Tefzel ${ }^{\Phi}$ were heated to approximately $149^{\circ} \mathrm{C}$ under vacuum $\left(10^{-6}\right.$ to $10^{-7}$ torr) to drive off contaminant products. Z-93P samples were mounted on a watercooled sample plate approximately $15.2 \mathrm{~cm}$ from the contamination source along with a quartz crystal microbalance (QCM) used to measure thickness of the deposited contaminants. A low pressure mercury near ultraviolet (NUV) lamp illuminated the sample plate, including the QCM, during and after the deposition for a total NUV exposure of 16 hours. It was expected that NUV would fix the contaminants and reduce re-evaporation of the contaminants from the sample plate. Samples purposely contaminated with Tefzel ${ }^{\otimes}$ outgassing products in this manner were labeled 365-1, 365-2, and 365-3. A sample of Z-93P labeled A-100 was not exposed to Tefzel ${ }^{\circledR}$ outgassing products and was used as a witness sample during VUV exposure testing. Although this sample was prepared from a different Z$93 \mathrm{P}$ paint batch than those which were coated with Tefzel ${ }^{\Phi}$ outgassing, products, it was expected to be a typical Z93P sample comparable in VUV-durability to the $365-1,-2$, and -3 sarnples in order to determine the effects of the Tefzel $^{\otimes}$ contamination. 


\subsubsection{VUV Exposure and Sample Characterization Procedures}

The three Tefzel ${ }^{\otimes}$-contaminated Z-93P samples and one witness Z-93P sample were exposed in vacuum to four increments of VUV exposure. Total test duration was 234 hours. In addition to in-air reflectance data obtained before and after the test, in-vacuum reflectance data were obtained prior to VUV exposure and immediately after each increment. The VUV lamp pair used to illuminate the four sample holder was calibrated prior to the first exposure increment and after the final increment. VUV intensity and equivalent sun hours (ESH) for each sample will be provided in section 3.1 .

\subsection{AO-VUV EXPOSURE OF SILVERED TEFLON ${ }^{\circledR}$ AND $^{\text {SIO }}$-COATED SILVERED TEFLON $^{\circledR}$}

\subsubsection{Samples}

Two separate tests were conducted to evaluate uncoated and $\mathrm{SiO}_{\mathrm{x}}$ (where $\mathrm{x} \approx 2$ )-coated silvered Teflon ${ }^{\otimes E P}$. In AO-VUV Test 1, three samples of $\mathrm{SiO}_{\mathrm{x}}$-coated silvered Teflon ${ }^{\circledR}$ FEP labeled SST-1, SST-2 and SST-4 and one Z93P sample labeled ZPLM-1 were tested. In AO-VUV Test 2, three samples of uncoated silvered Teflon ${ }^{\otimes}$ FEP labeled UST-2, UST-3 and UST-4 and one Z-93P sample labeled ZPLM-5 were exposed. Table 2 shows the composition of each sample including the thickness of each layer. All samples were $2.38 \mathrm{~cm}$ diameter.

TABLE 2. Samples for AO-VUV Exposure

\begin{tabular}{|c|c|c|c|c|c|c|c|}
\hline Test & $\begin{array}{l}\text { Sample } \\
\text { Position }\end{array}$ & $\begin{array}{l}\text { Sample } \\
\text { Label }\end{array}$ & $\begin{array}{l}\text { Layer } 1 \\
\text { on } \mathrm{Al} \text { substrate }\end{array}$ & Layer 2 & Layer3 & Layer 4 & Layer 5 \\
\hline $\begin{array}{l}\text { AO-VUV } \\
\text { Test } 1\end{array}$ & 3 & $\begin{array}{l}\text { SST-1 } \\
\text { SST-2 } \\
\text { ZPLM-1 } \\
\text { SST-4 }\end{array}$ & $\begin{array}{l}\text { acrylic adhesive } \\
\text { acrylic adhesive } \\
\text { Z-93P } \\
0.10 \text { to } 0.13 \mathrm{~mm} \\
\text { acrylic adhesive }\end{array}$ & $\begin{array}{l}\text { Inconel }^{\Phi} \\
27.5 \mathrm{~nm} \\
\text { Inconel }^{\Phi} \\
27.5 \mathrm{~nm} \\
-- \\
\\
\text { Inconel } \\
27.5 \mathrm{~nm}\end{array}$ & $\begin{array}{l}\text { Silver } \\
100 \mathrm{~nm} \\
\text { Silver } \\
100 \mathrm{~nm} \\
-- \\
\\
\text { Silver } \\
100 \mathrm{~nm} \\
\end{array}$ & $\begin{array}{l}\text { Teflon }^{\otimes} \text { FEP } \\
0.140 \mathrm{~mm} \\
\text { Teflon }{ }^{\star} \text { FEP } \\
0.140 \mathrm{~mm} \\
- \\
\\
\text { Teflon }^{\otimes} \text { FEP } \\
0.140 \mathrm{~mm}\end{array}$ & $\begin{array}{l}\mathrm{SiO}_{\mathrm{x}} \\
115 \mathrm{~nm} \\
\mathrm{SiO}_{\mathrm{x}} \\
115 \mathrm{~nm} \\
-- \\
\\
\mathrm{SiO}_{\mathrm{x}} \\
115 \mathrm{~nm} \\
\end{array}$ \\
\hline $\begin{array}{l}\text { AO-VUV } \\
\text { Test } 2\end{array}$ & $\begin{array}{l}2 \\
3\end{array}$ & $\begin{array}{l}\text { UST-3 } \\
\text { UST-2 } \\
\text { ZPLM-5 } \\
\text { UST-4 }\end{array}$ & $\begin{array}{l}\text { acrylic adhesive } \\
\text { acrylic adhesive } \\
\text { Z-93P } \\
0.10 \text { to } 0.13 \mathrm{~mm} \\
\text { acrylic adhesive }\end{array}$ & $\begin{array}{l}\text { Inconel }^{\otimes} \\
27.5 \mathrm{~nm} \\
\text { Inconel }^{\otimes} \\
27.5 \mathrm{~nm} \\
-- \\
\\
\text { Inconel }^{\otimes} \\
27.5 \mathrm{~nm}\end{array}$ & $\begin{array}{l}\text { Silver } \\
100 \mathrm{~nm} \\
\text { Silver } \\
100 \mathrm{~nm} \\
-- \\
\\
\text { Silver } \\
100 \mathrm{~nm}\end{array}$ & $\begin{array}{l}\text { Teflon }{ }^{\circledR} \text { FEP } \\
0.254 \mathrm{~mm} \\
\text { Teflon }{ }^{\star} \text { FEP } \\
0.254 \mathrm{~mm} \\
-- \\
\\
\text { Teflon }^{\otimes} \text { FEP } \\
0.254 \mathrm{~mm}\end{array}$ & $\begin{array}{l}- \\
- \\
- \\
-\end{array}$ \\
\hline
\end{tabular}

\subsubsection{Exposure Procedures}

In AO-VUV Test 1 , the samples described in Table 2 were exposed to AO and VUV radiation simultaneously in four increments. Total test duration was 260.2 hours. In AO-VUV Test 2, the samples described in Table 2 were exposed to AO and VUV radiation simulatneously in three increments. Total test duration was 250.7 hours. In addition to in-air reflectance data obtained before and after each test, in-vacuum reflectance data were obtained prior to AO-VUV exposure and immediately after each increment. The VUV lamp pair used to illuminate the four sample holder was calibrated before and after Test 1 . Test 2 was conducted immediately following Test 1 ; therefore the calibration data following Test 1 is valid for the pre-test calibration prior to Test 2 . VUV lamp output following Test 2 was not measured due to equipment problems; however, it was estimated. VUV intensity, VUV ESH, AO flux and AO fluence for each test will be provided in section 3.2. 


\section{Results And Discussion}

\subsection{TEFZEL $^{\circledR}$-CONTAMINATED Z-93P EXPOSED TO VUV WITHOUT AO}

\subsubsection{VUV Lamp Calibration}

The measured number of VUV suns for each sample position, before and after VUV exposure testing, are shown in Table 3. It is evident that the VUV lamps experienced a significant loss of intensity due to the total 234 hours of use. It is likely that contaminants present in the facility, probably due to perfluorinated polyether vacuum pump oil, were deposited onto the $\mathrm{MgF}_{2}$ windows of the VUV lamps and were "fixed" onto the windows due to the intense VUV radiation formed inside the lamp.

TABLE 3. Measured Number of VUV Suns at Each Sample Exposure Position

\begin{tabular}{|c|c|c|c|c|}
\hline $\begin{array}{l}\text { Exposure } \\
\text { Position }\end{array}$ & Sample Type & $\begin{array}{l}\text { Sample } \\
\text { Label }\end{array}$ & $\begin{array}{l}\text { No. VUV Suns } \\
\text { Pre-test }\end{array}$ & $\begin{array}{l}\text { No. VUV Suns } \\
\text { Post-test, } 234 \text { hrs }\end{array}$ \\
\hline 1 & Tefzel ${ }^{\otimes}$-contaminated Z-93P & $365-1$ & 8.8 & 1.1 \\
\hline 2 & Tefzel ${ }^{\otimes}$-contaminated Z-93P & $365-2$ & 10.5 & 1.7 \\
\hline 3 & Z-93P witness & A-100 & 13 & 1.2 \\
\hline 4 & Tefzel ${ }^{\star}$-contaminated Z-93P & $365-3$ & 10.6 & 2.0 \\
\hline
\end{tabular}

It was assumed that the lamp intensity degraded following an exponential decay function as shown in Figure 2 . The number of suns before and after each of the four exposure increments was interpolated from the exponential decay curve fit of the data for each exposure position. Then the average number of suns for each increment was obtained from these data. Table 4 shows the curve fit equations and the calculated average number of suns for each exposure increment.

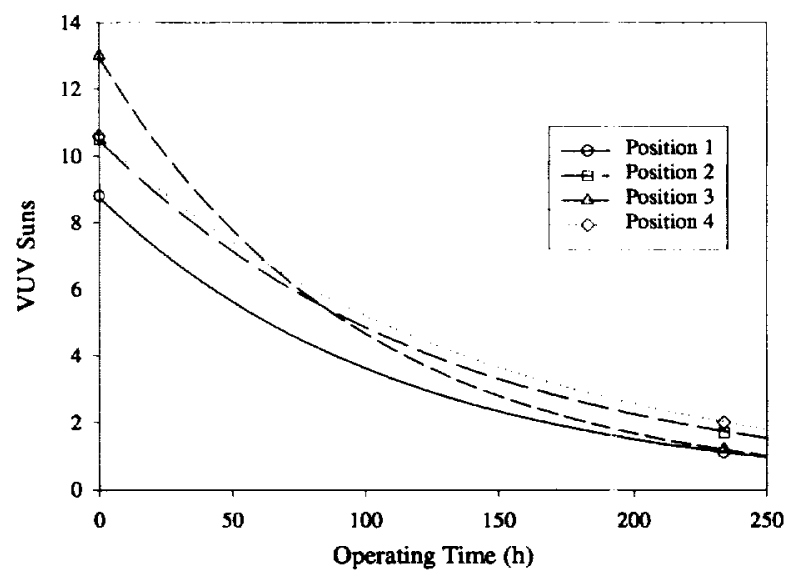

Figure 2: VUV lamp intensity as a function o: operating time 
TABLE 4. Calculated Number of VUV Suns

\begin{tabular}{|c|c|c|c|c|}
\hline $\begin{array}{l}\text { Sample Holder Position } \\
\text { Sample Label }\end{array}$ & $\begin{array}{l}1 \\
365-1 \\
\end{array}$ & $\begin{array}{ll}2 \\
365-2 \\
\end{array}$ & $\begin{array}{l}3 \\
A-100\end{array}$ & $\begin{array}{ll}4 \\
365-3 \\
\end{array}$ \\
\hline $\begin{array}{l}\text { Exponential decay curve } \\
\text { fit, } \\
x=\text { operating hours, } \\
y=\text { no. of VUV suns }\end{array}$ & $\begin{array}{l}y= \\
\exp (2.2- \\
0.0088 x)\end{array}$ & $\begin{array}{l}y= \\
\exp (2.3- \\
0.0077 x)\end{array}$ & $\begin{array}{l}y= \\
\exp (2.6-0.010 x)\end{array}$ & $\begin{array}{l}y= \\
\exp (2.4- \\
0.0071 x)\end{array}$ \\
\hline Avg. no. VUV suns & & & & \\
\hline Inc. 1 & 7.2 & 8.9 & 10.4 & 9.0 \\
\hline Inc. 2 & 4.7 & 6.1 & 6.4 & 6.4 \\
\hline Inc. 3 & 3.1 & 4.2 & 3.9 & 4.6 \\
\hline Inc. 4 & 1.8 & 2.6 & 2.1 & 2.9 \\
\hline
\end{tabular}

\subsubsection{Solar Absorptance Measurements}

The solar absorptance values in the wavelength range 280-2500 nm measured in vacuum at each VUV exposure increment are shown in Figure 3. Table 5 shows solar absorptance values before and after VUV exposure and the overall change in solar absorptance for each sample. Also shown are changes in solar absorptance per ESH of VUV exposure.

As indicated in Table 5, the change in solar absorptance per ESH for Tefzel ${ }^{8}$-contaminated Z-93P is 1.9 to 2.7 times that of the uncontaminated Z-93P witness sample. Therefore, it can be concluded that deposition of the outgassed products of Tefzel ${ }^{\oplus}$ onto Z-93P will cause degradation in solar absorptance of Z-93P to occur at a faster rate than solar absorptance degradation of Z-93P which has not been exposed to Tefzel ${ }^{(B)}$ outgassing products. Equivalent ISS radiator VUV exposure years are shown for reference. However, it is not valid to assume that these would be the actual changes in solar absorptance for the equivalent ISS radiator LEO exposure duration, because other LEO environmental effects to which ISS radiators will be exposed were not simulated here. This test provides a worstcase scenario for solar absorptance degradation of Tefzel ${ }^{\text {to }}$-contaminated Z-93P, particularly because atomic oxygen, to which many of the thermal control surfaces on ISS will be exposed, was not present during these tests. Other testing has shown that, following VUV exposure of Tefzel ${ }^{\circledR}$-contaminated Z-93P samples, atomic oxygen exposure causes reversal of solar absorptance degradation [5].

TABLE 5. In-Vacuum Measurements: Effect of VUV on Solar Absorptance of Tefzel ${ }^{\circ}$ Contaminated Z-93P and Z-93P Witness Sample

\begin{tabular}{|c|c|c|c|c|c|c|}
\hline Sample & $\begin{array}{c}\text { Total VUV } \\
\text { Exposure, } \\
\text { ESH }\end{array}$ & $\begin{array}{c}\text { Equivalent } \\
\text { ISS Radiator } \\
\text { VUV Exposure, } \\
\text { years }\end{array}$ & $\begin{array}{l}\text { Solar Ab: } \\
\text { Before } \\
\text { Exposure }\end{array}$ & $\begin{array}{l}\text { tance, } \alpha_{s} \\
\text { After } \\
\text { Exposure }\end{array}$ & $\Delta \alpha_{s}$ & $\Delta \alpha_{s} / \mathrm{ESH}$ \\
\hline $\begin{array}{c}\text { Tefzel }^{\otimes} \text {-contam., } \\
365-1 \\
\text { Tefzel }^{\otimes} \text {-contam., } \\
365-2 \\
\text { Tefzel }^{\otimes} \text {-contam., } \\
365-3 \\
\text { uncontaminated, } \\
\text { A-100 }\end{array}$ & $\begin{array}{l}1670 \\
2234 \\
2397 \\
2167\end{array}$ & $\begin{array}{l}4.9 \\
6.5 \\
7.0 \\
6.3\end{array}$ & $\begin{array}{l}0.154 \\
0.156 \\
0.168 \\
0.133\end{array}$ & $\begin{array}{l}0.208 \\
0.207 \\
0.236 \\
0.159\end{array}$ & $\begin{array}{l}0.054 \\
0.051 \\
0.068 \\
0.026\end{array}$ & $\begin{array}{l}3.2 \times 10^{-5} \\
2.3 \times 10^{-5} \\
2.8 \times 10^{-5} \\
1.2 \times 10^{-5}\end{array}$ \\
\hline
\end{tabular}




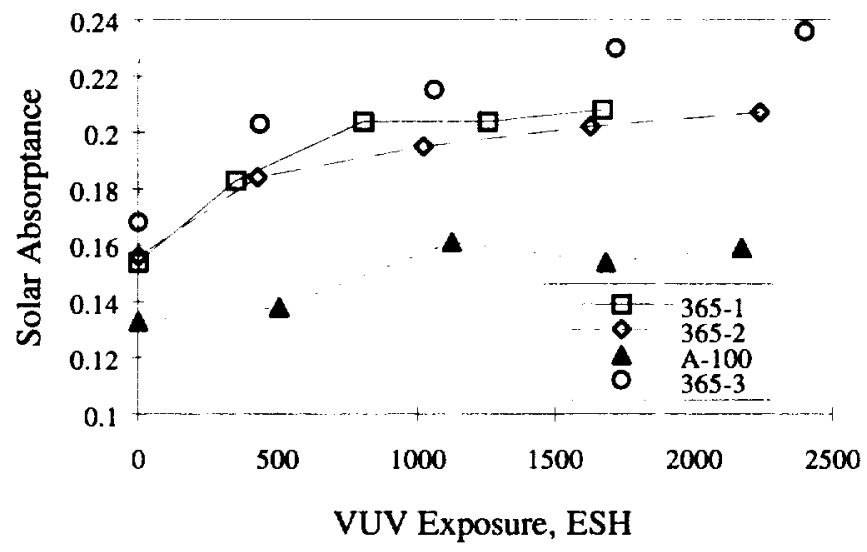

Figure 3: Solar absorptance of Tefzel ${ }^{\infty}$-contaminated Z-93P samples (365-1, -2, and -3) compared to an uncontaminated Z-93P witness sample (A-100).

Table 6 shows solar absorptance values for the wavelength range $250-2500 \mathrm{~nm}$ measured in air for the Tefzel ${ }^{\Phi}$. contaminated Z-93P samples and the Z-93P witness sample before and a ter VUV exposure.

TABLE 6. In-air Measurements: Effect of VUV on Solar Absorptance of Tefzel ${ }^{\circledR}$-Contaminated Z-93P and Z-93P Witness Sample

\begin{tabular}{|c|c|c|c|c|c|}
\hline Sample & $\begin{array}{l}\text { Total VUV } \\
\text { Exposure, } \\
\text { ESH }\end{array}$ & $\begin{array}{l}\text { Solar Absor } \\
\text { Before } \\
\text { Exposure }\end{array}$ & $\begin{array}{l}\text { tance, } x_{k} \\
\text { After } \\
\text { Exposure }\end{array}$ & $\Delta \alpha_{4}$ & $\Delta \alpha_{6} / \mathrm{ESH}$ \\
\hline $\begin{array}{l}\text { Tefzel" }\left.\right|^{*} \text {-contam., } 365-1 \\
\text { Tefzcl }{ }^{2} \text {-contam., } 365-2 \\
\text { Tefzel }{ }^{*} \text {-contam., } 365-3 \\
\text { uncontaminated, A-100 }\end{array}$ & $\begin{array}{l}1670 \\
2234 \\
2397 \\
2167\end{array}$ & $\begin{array}{l}0.144 \\
0.147 \\
0.146 \\
0.111\end{array}$ & $\begin{array}{l}0.182 \\
0.183 \\
0.188 \\
0.132\end{array}$ & $\begin{array}{l}0.038 \\
0.036 \\
0.042 \\
0.021\end{array}$ & $\begin{array}{l}2.3 \times 10^{-5} \\
1.6 \times 10^{-5} \\
1.8 \times 10^{-5} \\
0.96 \times 10^{-5}\end{array}$ \\
\hline
\end{tabular}

A comparison of the $\Delta \alpha$ values between the in-air data (Table 6) and in-vacuum data (Table 5) indicate that the inair values are lower. This difference is likely due to bleaching, or reversal, of VUV-induced darkening upon exposure of the samples to ambient conditions. Such bleaching would cause a reduction in the solar absorptance upon removal of samples from the vacuum chamber. The initial (before exposure) in-vacuum $\alpha_{s}$ values for the samples are higher than the in-air values indicating an increase upon exposure to the vacuum environment. While instrument error may account for some of the deviation, the consistency of an increase in $\alpha_{s}$ suggests another effect, possibly facility contamination.

\subsection{AO-VUV EXPOSURE OF SILVERED TEFLON ${ }^{\star}$ AND SIO $_{\mathrm{x}}$-COA TED SILVERED TEFLON ${ }^{\star}$}

\subsubsection{VUV Intensity and AO Flux Calibration}

Table 7 provides VUV lamp calibration data for the AO-VUV exposure tests. As indicated, the lamp intensity after AO-VUV Test 1 was higher than that prior to the test by approximately 10-20\%. In general, VUV lamp output does not increase with use as was observed here. Instead, lamp output has been observed to degrade. Degradation is minimal when lamps are used in the presence of $A O$, because contaminarts are removed by $A O$ as fast as they can be UV-fixed onto the lamp windows. The increase in output observed during AO-VUV Test 1 is expected to be due to AO-removal of contaminants that may have been present on the lamp windows prior to use. Because only two data points were obtained, it was not possible to determine whether the incre ase in lamp output occurred immediately or gradually. Because the change in output was fairly small, it was assurred to follow a linear increase with time for purposes of calculating the average number of suns for each exposure increment as shown in Table 7. It was further assumed that by the conclusion of Test 1 all contaminants were removed from the lamp window surfaces and that further use during Test 2 would cause lamp output to degrade following typical observations of 5\% intensity loss 
during a 250 hour test. Because facility problems prevented VUV intensity calibrations from being conducted following Test 2 , the average number of suns for this test were calculated using this assumption. Calculated values for the average number of suns during Test 2 are shown in Table 7.

TABLE 7. Number of VUV Suns at Each Sample Position for AO-VUV Tests

\begin{tabular}{c|c|c|c|c|c}
\hline $\begin{array}{c}\text { Sample } \\
\text { Position }\end{array}$ & $\begin{array}{c}\text { No. VUV } \\
\text { Suns } \\
\text { Before } \\
\text { AO-VUV } \\
\text { Test 1 }\end{array}$ & $\begin{array}{c}\text { No. VUV } \\
\text { Suns } \\
\text { After } \\
\text { AO-VUV } \\
\text { Test 1 }\end{array}$ & $\begin{array}{c}\text { Percent } \\
\text { Increase in } \\
\text { No. Suns, } \\
\text { AO-VUV } \\
\text { Test 1 }\end{array}$ & $\begin{array}{c}\text { Avg. No. } \\
\text { of Suns, } \\
\text { AO-VUV } \\
\text { Test 1 }\end{array}$ & $\begin{array}{c}\text { Avg. No. of Suns, } \\
\text { AO-VUV Test 2 }\end{array}$ \\
\hline 1 & 3.0 & 3.6 & 19.4 & 3.3 & 3.5 \\
2 & 3.9 & 4.5 & 16.5 & 4.2 & 4.4 \\
3 & 4.9 & 5.4 & 9.7 & 5.1 & 5.2 \\
4 & 3.7 & 4.0 & 9.6 & 3.9 & 3.9 \\
\hline
\end{tabular}

The effective atomic oxygen flux values during AO-VUV Test 1 and Test 2 were obtained by measuring the mass of Teflon ${ }^{8}$ FEP witness samples before and after each test. Test 1 flux was measured to be $4.73 \times 10^{15}$ atoms $/ \mathrm{cm}^{2} \mathrm{~s}$, and Test 2 flux was measured to be $4.62 \times 10^{15}$ atoms $/ \mathrm{cm}^{2} \mathrm{~s}$.

\subsubsection{Optical Properties Measurements}

Results of in-vacuum solar absorptance measurements for samples exposed in AO-VUV Test 1 and Test 2 are shown in Table 8 and Table 9, respectively. In-air measurements for both tests are shown in Table 10. The purpose of these tests was to determine the effects of combined $\mathrm{AO}$ and $\mathrm{VUV}$ on $\mathrm{SiO}_{\mathrm{x}}$-coated silvered Teflon and uncoated silvered Teflon ${ }^{\circledast 2}$ as compared to Z-93P. Because each sample received a somewhat different ratio of AO fluence/VUV ESH, for simplicity in interpreting data, results are displayed in tabular form and not in graphical form. Based on the $\Delta \alpha_{s}$ values, there are no consistent increases or decreases in solar absorptance with increasing AOVUV exposure. The values of $\Delta \alpha_{s}$, indicate changes that are within experimental error of the measurement throughout the tests. For the coated and uncoated silvered Teflon materials and Z-93P, it was verified that at AO and VUV fluences representative of 2.5 to 4 years for ISS radiators, there are no significant changes in solar absorptance. In-air measurements also indicate changes within experimental error of the measurements.

TABLE 8. In-vacuum Measurements: Effect of AO and VUV on Solar Absorptance of SiO $_{\mathrm{x}}$-coated Silvered Teflon ${ }^{\otimes}$ (SST) and Z-93P (ZPLM) Samples

\begin{tabular}{c|c|c|c|c|c|c}
\hline Sample & $\begin{array}{c}\text { VUV } \\
\text { ESH }\end{array}$ & $\begin{array}{c}\text { AO Fluence } \\
\text { (atoms } / \mathrm{cm}^{2} \text { ) }\end{array}$ & $\begin{array}{c}\text { ISS Radiator } \\
\text { Equivalent } \\
\text { VUV years }\end{array}$ & $\begin{array}{c}\text { ISS Radiator } \\
\text { Equivalent } \\
\text { AO years }\end{array}$ & $\alpha_{s}$ & $\begin{array}{c}\Delta \alpha_{s} \\
\text { from } \mathrm{t}_{0}\end{array}$ \\
\hline SST-1 & 0 & 0 & 0 & 0 & 0.092 & \\
& 156 & $8.12 \times 10^{20}$ & 0.45 & 0.74 & 0.081 & -0.011 \\
& 462 & $2.40 \times 10^{21}$ & 1.34 & 2.18 & 0.088 & -0.004 \\
& 465 & $2.41 \times 10^{21}$ & 1.35 & 2.19 & 0.091 & -0.001 \\
& 853 & $4.43 \times 10^{21}$ & 2.48 & 4.03 & 0.087 & -0.005 \\
\hline SST-2 & 0 & 0 & 0 & 0 & 0.093 & \\
& 201 & $8.12 \times 10^{20}$ & 0.58 & 0.74 & 0.081 & -0.012 \\
& 593 & $2.40 \times 10^{21}$ & 1.72 & 2.18 & 0.091 & -0.002 \\
& 597 & $2.41 \times 10^{21}$ & 1.73 & 2.19 & 0.083 & -0.010 \\
& 1095 & $4.43 \times 10^{21}$ & 3.18 & 4.03 & 0.089 & -0.004 \\
\hline SST-4 & 0 & 0 & 0 & 0 & 0.102 & \\
& 184 & $8.12 \times 10^{20}$ & 0.53 & 0.74 & 0.090 & -0.012 \\
& 544 & $2.40 \times 10^{21}$ & 1.58 & 2.18 & 0.094 & -0.008 \\
& 547 & $2.41 \times 10^{21}$ & 1.59 & 2.19 & 0.096 & -0.006 \\
& 1004 & $4.43 \times 10^{21}$ & 2.92 & 4.03 & 0.086 & -0.016 \\
\hline ZPLM-1 & 0 & 0 & 0 & 0 & 0.148 & \\
& 245 & $8.12 \times 10^{20}$ & 0.71 & 0.74 & 0.150 & 0.002 \\
& 724 & $2.40 \times 10^{21}$ & 2.10 & 2.18 & 0.160 & 0.012 \\
& 728 & $2.41 \times 10^{21}$ & 2.12 & 2.19 & 0.151 & 0.003 \\
& 1337 & $4.43 \times 10^{21}$ & 3.89 & 4.03 & 0.151 & 0.003 \\
\hline
\end{tabular}


TABLE 9. In-vacuum Measurements: Effect of AO and VUV on Sola- Absorptance of Silvered Teflon ${ }^{\otimes}$ (UST) and Z-93P (ZPLM) Samples

\begin{tabular}{c|c|c|c|c|c|c}
\hline Sample & $\begin{array}{c}\text { VUV } \\
\text { ESH }\end{array}$ & $\begin{array}{c}\text { AO Fluence } \\
\left.\text { (atoms } / \mathrm{cm}^{2}\right)\end{array}$ & $\begin{array}{c}\text { ISS Radiator } \\
\text { Equivalent } \\
\text { VUV years }\end{array}$ & $\begin{array}{c}\text { ISS Ratiator } \\
\text { Equivialent } \\
\text { AO years }\end{array}$ & $\alpha_{s}$ & $\begin{array}{c}\Delta \alpha_{s} \\
\text { from } \mathrm{t}_{0}\end{array}$ \\
\hline UST-2 & 0 & 0 & 0 & 0 & 0.050 & \\
& 287 & $1.08 \times 10^{21}$ & 0.83 & 0.99 & 0.064 & 0.014 \\
& 785 & $2.97 \times 10^{21}$ & 2.28 & 2.70 & 0.052 & 0.002 \\
& 1103 & $4.17 \times 10^{21}$ & 3.21 & 3.79 & 0.056 & 0.006 \\
\hline UST-3 & 0 & 0 & 0 & 0 & 0.057 & \\
& 228 & $1.08 \times 10^{21}$ & 0.66 & 0.99 & 0.067 & 0.010 \\
& 624 & $2.97 \times 10^{21}$ & 1.81 & 2.70 & 0.056 & -0.001 \\
& 878 & $4.17 \times 10^{21}$ & 2.55 & 3.79 & 0.053 & -0.004 \\
\hline UST-4 & 0 & 0 & 0 & 0 & 0.050 & \\
& 254 & $1.08 \times 10^{21}$ & 0.74 & 0.99 & 0.064 & 0.014 \\
& 695 & $2.97 \times 10^{21}$ & 2.02 & 2.70 & 0.057 & 0.007 \\
& 978 & $4.17 \times 10^{21}$ & 2.84 & 3.79 & 0.055 & 0.005 \\
\hline ZPLM- & 0 & 0 & 0 & 0 & 0.119 & \\
5 & & & & & & \\
& 339 & $1.08 \times 10^{21}$ & 0.98 & 0.99 & 0.121 & 0.002 \\
& 927 & $2.97 \times 10^{21}$ & 2.69 & 2.70 & 0.124 & 0.005 \\
& 1304 & $4.17 \times 10^{21}$ & 3.79 & 3.79 & 0.118 & -0.001 \\
\hline
\end{tabular}

TABLE 10. In-air Measurements: Effect of AO and VUV on Solar Absorptance of $\mathrm{SiO}_{\mathbf{x}}$-coated Silvered Teflon ${ }^{\circledR}$, uncoated Silvered Teflon ${ }^{\oplus}$ and Z-93P.

\begin{tabular}{|c|c|c|c|c|c|c|}
\hline Sample & $\begin{array}{l}\text { VUV } \\
\text { ESH }\end{array}$ & $\begin{array}{l}\text { AO Fluence } \\
\text { (atoms } / \mathrm{cm}^{2} \text { ) }\end{array}$ & $\begin{array}{l}\text { ISS Radiator } \\
\text { Equivalent } \\
\text { VUV years } \\
\end{array}$ & $\begin{array}{l}\text { ISS F.adiator } \\
\text { Equivalent } \\
\text { AO years }\end{array}$ & $\overline{\alpha_{s}}$ & $\begin{array}{c}\Delta \alpha_{s} \\
\text { from } t_{0}\end{array}$ \\
\hline SST-1 & $\begin{array}{c}0 \\
853 \\
\end{array}$ & $\begin{array}{c}0 \\
4.43 \times 10^{21} \\
\end{array}$ & $\begin{array}{c}0 \\
2.48\end{array}$ & $\begin{array}{c}0 \\
4.03\end{array}$ & $\begin{array}{l}0.072 \\
0.070\end{array}$ & -0.002 \\
\hline SST-2 & $\begin{array}{c}0 \\
1095 \\
\end{array}$ & $\begin{array}{c}0 \\
4.43 \times 10^{21} \\
\end{array}$ & $\begin{array}{c}0 \\
3.18 \\
\end{array}$ & $\begin{array}{c}0 \\
4.03 \\
\end{array}$ & $\begin{array}{l}0.072 \\
0.074 \\
\end{array}$ & 0.002 \\
\hline SST-4 & $\begin{array}{c}0 \\
1004 \\
\end{array}$ & $\begin{array}{c}0 \\
4.43 \times 10^{21} \\
\end{array}$ & $\begin{array}{c}0 \\
2.92 \\
\end{array}$ & $\begin{array}{c}0 \\
4.03 \\
\end{array}$ & $\begin{array}{l}0.069 \\
0.062 \\
\end{array}$ & -0.007 \\
\hline UST-2 & $\begin{array}{c}0 \\
1103 \\
\end{array}$ & $\begin{array}{c}0 \\
4.17 \times 10^{2 !} \\
\end{array}$ & $\begin{array}{c}0 \\
3.21 \\
\end{array}$ & $\begin{array}{c}0 \\
379 \\
\end{array}$ & $\begin{array}{l}0.064 \\
0.060 \\
\end{array}$ & -0.004 \\
\hline UST-3 & $\begin{array}{c}0 \\
878 \\
\end{array}$ & $\begin{array}{c}0 \\
4.17 \times 10^{21} \\
\end{array}$ & $\begin{array}{c}0 \\
2.55 \\
\end{array}$ & $\begin{array}{c}0 \\
3.79 \\
\end{array}$ & $\begin{array}{l}0.065 \\
0.060 \\
\end{array}$ & -0.005 \\
\hline UST-4 & $\begin{array}{c}0 \\
978 \\
\end{array}$ & $\begin{array}{c}0 \\
4.17 \times 10^{21} \\
\end{array}$ & $\begin{array}{c}0 \\
2.84 \\
\end{array}$ & $\begin{array}{c}0 \\
379 \\
\end{array}$ & $\begin{array}{l}0.064 \\
0.061 \\
\end{array}$ & -0.003 \\
\hline ZPLM-1 & $\begin{array}{c}0 \\
1337 \\
\end{array}$ & $\begin{array}{c}0 \\
4.43 \times 10^{21} \\
\end{array}$ & $\begin{array}{c}0 \\
3.89 \\
\end{array}$ & $\begin{array}{c}0 \\
4.03\end{array}$ & $\begin{array}{l}0.132 \\
0.125\end{array}$ & -0.007 \\
\hline ZPLM-5 & $\begin{array}{c}0 \\
1304\end{array}$ & $\begin{array}{c}0 \\
4.17 \times 10^{21} \\
\end{array}$ & $\begin{array}{c}0 \\
3.79 \\
\end{array}$ & $\begin{array}{c}0 \\
379 \\
\end{array}$ & $\begin{array}{l}0.117 \\
0.110 \\
\end{array}$ & -0.007 \\
\hline
\end{tabular}

Thermal emittance values for samples exposed in AO-VUV Tests 1 and 2 were measured as shown in Table 11. Samples were measured following AO-VUV exposure and values were compared with emittances measured for pristine samples. 
Public reporting burden for this collection of information is estimated to average 1 hour per response, including the time for reviewing instructions, searching existing data sources, gathering and maintaining the data needed, and completing and reviewing the collection of information. Send comments regarding this burden estimate or any other aspect of this

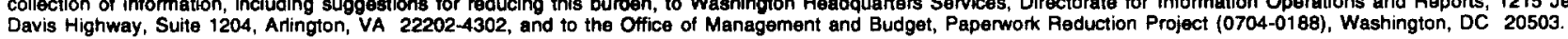

\begin{tabular}{l|l|l} 
1. AGENCY USE ONLY (Leave blank) & $\begin{array}{c}\text { 2. REPORT DATE } \\
\text { August } 1998\end{array}$ & $\begin{array}{c}\text { 3. REPOAT TYPE AND DATES COVERED } \\
\text { Technical Memorandum }\end{array}$
\end{tabular}

\section{TITLE AND SUBTITLE}

Evaluation of Low Earth Orbit Environmental Effects on International Space Station Thermal Control Materials

6. AUTHOR(S)

5. FUNDING NUMBERS

Joyce A. Dever, Sharon K. Rutledge, Mark M. Hasegawa, and Charles K. Reed

\section{PERFORMING ORGANIZATION NAME(S) AND ADDRESS(ES)}

National Aeronautics and Space Administration

Lewis Research Center

Cleveland, Ohio 44135-3191

9. SPONSORINGMONITORING AGENCY NAME(S) AND ADDRESS(ES)

National Aeronautics and Space Administration

Washington, DC 20546-0001
WU-632-1A-1E-00

8. PERFORMING ORGANIZATION REPORT NUMBER

E-11298

\section{SUPPLEMENTARY NOTES}

Prepared for the International Conference on Protection of Materials in a Space Environment sponsored by the University of Toronto Institute for Aerospace Studies, Toronto, Canada, April 23-24, 1998. Joyce A. Dever and Sharon K. Rutledge, NASA Lewis Research Center; Mark M. Hasegawa, Boeing Space and Defense Systems, Huntington Beach, California 92647; Charles K. Reed, Lockheed Martin Vought Systems, Dallas, Texas 75265. Responsible person, Joyce A. Dever, organization code 5480, (216) 433-6294.

12a. DISTRIBUTIONAVAILABILITY STATEMENT

Unclassified - Unlimited

Subject Category: 27

Distribution: Nonstandard

This publication is available from the NASA Center for AeroSpace Information, (301) 621-0390.

13. ABSTRACT (Maximum 200 words)

Samples of International Space Station (ISS) thermal control coatings were exposed to simulated low Earth orbit (LEO) environmental conditions to determine effects on optical properties. In one test, samples of the white paint coating Z-93P were coated with outgassed products from Tefzel ${ }^{\circledR}$ (ethylene tetrafluoroethylene copolymer) power cable insulation as may occur on ISS. These samples were then exposed, along with an uncontaminated Z-93P witness sample, to vacuum ultraviolet (VUV) radiation to determine solar absorptance degradation. The Z-93P samples coated with Tefzel ${ }^{\circledR}$ outgassing products experienced greater increases in solar absorptance than witness samples not coated with Tefzel ${ }^{\circledR}$ outgassing products. In another test, samples of second surface silvered Teflon ${ }^{\circledR}$ FEP (fluorinated ethylene propylene), SiO $_{x}$ (where $x \approx 2$ )-coated silvered Teflon ${ }^{\circledR}$ FEP, and Z-93P witness samples were exposed to the combined environments of atomic oxygen and VUV radiation to determine optical properties changes due to these simulated ISS environmental effects. This test verified the durability of these materials in the absence of contaminants.

\section{SUBJECT TERMS}

Environmental effects; International Space Station; Thermal control materials

\begin{tabular}{|c|c|}
\hline $\begin{array}{c}\text { 17. SECURITY CLASSIFICATION } \\
\text { OF REPORT } \\
\text { Unclassified }\end{array}$ & $\begin{array}{c}\text { 18. SECURTY CLASSIFICATION } \\
\text { OF THIS PAGE } \\
\text { Unclassified }\end{array}$ \\
\hline
\end{tabular}
19. SECURITY CLASSIFICATION OF ABSTRACT Unclassified

15. NUMBER OF PAGES 17

16. PRICE CODE

$\mathrm{A03}$

20. LIMITATION OF ABSTRACT

Standard Form 298 (Rev. 2-89) Prescribed by ANSI Std. Z39-18 298-102 
TABLE 11. In-air Measurements: Effect of AO and VUV on Thermal Emittince of SiO $_{\mathbf{x}}$-coated Silvered Teflon ${ }^{\infty}$, uncoated Silvered Teflon ${ }^{\infty}$ and Z-93P.

\begin{tabular}{c|c|c|c|c|c|c}
\hline Sample & $\begin{array}{c}\text { VUV } \\
\text { ESH }\end{array}$ & $\begin{array}{c}\text { AO Fluence } \\
\left(\text { atoms } / \mathrm{cm}^{2} \text { ) }\right.\end{array}$ & $\begin{array}{c}\text { ISS Radiator } \\
\text { Equivalent } \\
\text { VUV years }\end{array}$ & $\begin{array}{c}\text { ISS Radiator } \\
\text { Equivalent } \\
\text { AO years }\end{array}$ & $\varepsilon$ & $\begin{array}{c}\Delta \varepsilon \text { from } \\
\text { pristine } \\
\text { sample }\end{array}$ \\
\hline SST-5 & 0 & 0 & 0 & 0 & 0.810 & \\
SST-1 & 853 & $4.43 \times 10^{21}$ & 2.48 & 4.03 & 0.811 & 0.001 \\
SST-2 & 1095 & $4.43 \times 10^{21}$ & 3.18 & 4.03 & 0.809 & -0.001 \\
SST-4 & 1004 & $4.43 \times 10^{21}$ & 2.92 & 4.03 & 0.808 & -0.002 \\
UST-1 & 0 & 0 & 0 & $1)$ & 0.859 & \\
UST-2 & 1103 & $4.17 \times 10^{21}$ & 3.21 & 3.79 & 0.853 & -0.006 \\
UST-3 & 878 & $4.17 \times 10^{21}$ & 2.55 & 3.79 & 0.857 & -0.002 \\
UST-4 & 978 & $4.17 \times 10^{21}$ & 2.84 & 3.79 & 0.857 & -0.002 \\
ZPLM-2 & 0 & 0 & 0 & 0 & 0.911 & \\
ZPLM-1 & 1337 & $4.43 \times 10^{21}$ & 3.89 & 4.03 & 0.911 & 0 \\
ZPLM-5 & 1304 & $4.17 \times 10^{21}$ & 3.79 & 3.79 & 0.909 & -0.002 \\
\hline
\end{tabular}

All changes in emittance were within experimental error, indicating no significant changes in emittance due to AOVUV exposure. A reduction in emittance for silvered Teflon ${ }^{\circledR}$ would be expected if enough of the Teflon ${ }^{\otimes}$ material was eroded by atomic oxygen. For the exposure fluences provided in AO-VUV Tests 1 and 2, erosion was not significant enough to cause emittance degradation.

\section{Conclusions}

VUV-induced solar absorptance degradation of the of Z-93P white paint ISS radiator coating occurred at a faster rate for samples coated with outgassed products from radiation crosslinked Tefzel ${ }^{\star}$ than for samples not coated with Tefzel $^{\otimes}$ products when both were exposed to VUV equivalent sun hours representative of 4.5 to 7 years on ISS. Tefzel $^{\Phi}$ power cable insulation is a possible source of contamination for ISS radiators. Solar absorptance increases of approximately 0.04 for the Tefzel ${ }^{\$}$-contaminated Z-93P coatings were indicative of worst-case testing where AO, which could reverse solar absorptance degradation, was not present.

$\mathrm{SiO}_{\mathrm{x}}$-coated and uncoated silvered $\mathrm{Teflon}^{\otimes}$ samples, along with $\mathrm{Z}$ - $\mathrm{SP}$ P witness samples, were exposed to the combined environments of AO and VUV for ISS radiator equivalent txposures of 2.5 to 4 years. These samples were not previously exposed to outgassed products from Tefzel ${ }^{\star}$. Samples exposed in these tests showed changes in solar absorptance and thermal emittance that were within instrument enor indicating durability of these materials to the ISS environment for this level of exposure where contaminants were not present.

\section{References}

1. Bailey, V., Janicki, G. C., and Haulik, T., eds., Proceedings of the $38^{\text {th }}$ International SAMPE Symposium and Exhibition, Volume 38 , Book 1. Stidham, C. R., Stueber, T. J., Banks, B. A., Dever, J. A., Rutledge, S. K., an I Bruckner, E. J., "Low Earth Orbital Atomic Oxygen Environmental Simulation Facility for Space Materials Evaluation," pp. 649-663, Society for the Advancement of Material and Process Engineering, 1993. Also: NASA Technical Memorandum 106128, May 1993.

2. Bailey, V., Janicki, G. C., and Haulik, T., eds., Proceedings of the $38^{\text {th }}$ International SAMPE Symposium and Exhibition, Volume 38, Book 1. Dever, J. A., Rutledge, S. K., Bruckner, E. J., Stidham, C. R., Stueber, T. J., Bcoth, R. E., "The Effects of Simulated Low Earth Orbit Environments on Spacecraft Thermal Control Coatings," pp. 694-706, Society for the Advancement of Material and Process Engineering, 1993. Also: NASA Technical Memorandum 106146, May 1993.

3. Banks, B. A., Dever, J. A., Gebauer, L., Hill, C., "Atomic Oxygen Interactions with FliP Teflon and Silicones on LDEF," LDEF - 69 Months in Space, NASA CP 3134, Part 2, June 1991, pp. 801-815.

4. ASTM E 903, "Standard Test Method for Solar Absorptance, Reflectance, and Trinsmittance of Materials Using Integrating Spheres," E 903-82 (Reapproved 1992).

5. Hasegawa, M. M., "VUV Darkening of Z-93P contaminated With Outgassed Products from Tefzel Insulated Power Cables," McDonnell Douglas Aerospace Report No. MDC 96H0305, January 1996. 